\title{
先鋭電極近傍に形成される交流電場誘起流動*
}

\author{
小原弘道*1，田代伸一*1
}

\section{AC Electric Field Induced Flow around a Sharp Electrode}

\author{
Hiromichi OBARA*1 and Shinichi TASHIRO \\ ${ }^{* 1}$ Department of Mechanical Engineering, Tokyo Metropolitan University \\ 1-1 Minami-Osawa Hachioji, Tokyo, 192-0397, Japan
}

\begin{abstract}
A micro scale flow structure induced with AC (alternating current) electric field around a sharp electrode in a particle dispersion fluid was investigated using a micro particle image velocimetry. This flow structure consists of a micro jet from the tip of the sharp electrode and circulation flows around it. This flow structure has great advantage of applications for a DNA or CNT manipulating and this is available for a micro fluidic device and novel nano scale manufacturing process. It is easy that the flow structure is controlled with a shape of the electrode and the AC electric field conditions. In this study, it was clear that the slant severed type electrode is able to generate the stable micro flow structure around a tip of the sharp electrode and the local velocity of this flow structure increases directly with the square of the electric field intensity. These results suggest that this flow induced with the alternating electric field is concerned with the dielectric properties of particles and this flow structure is able to control with the shape of the electrode.
\end{abstract}

Key Words : Micro Jet, Micro Fluidic Device, Dielectrophoresis, Micro-PIV, Flow Visualization

\section{1. 緒言}

環境親和型の微細加工技術をはじめとしてバイオ技術，次世代医療技術までの広範囲にわたる技術革新のため に，マイクロからナノスケールにかけての流動構造制御・形成は重要である．様々な要求のなかで，局所的に形 成されるせん断流や噴流，渦構造を有する流れなどマイクロスケールの流れを積極的に活用することは，既存技 術では難しい微小局所領域においての流れや粒子の制御・操作が可能となり, 様々な分野への応用が期待される. たとえば, 次世代型医療技術のためのバイオ・ナノ技術の要求の中で, 微小領域においてタンパク質やウィルス, 細菌，血球，細胞操作の一つの技術として粒子状物質分散溶液中に交流電場を印加寸ることで形成される誘電泳 動を積極的に利用寸る技術に関する研究(1)-(3)が幅広くおこなわれている. 誘電泳動は, 粒子状物質と溶媒との誘 電・導電特性から局所的に形成される電場の勾配を活用して粒子状物質の位置，配向を制御寸るものであり，電 場周波数により操作方向を制御可能なことから，交流電場が多くの場合利用されている．一方，交流電場印加に よって電極表面上に形成される電気二重層により誘起される流動に着目し，半導体製造技術の援用により作成し た微小平面電極上に交流電場印加により誘起される流動に着目した先駆的な研究(4)-(6)をはじめとして, 多くの研 究が進められている. MEMS 技術の進展の中で幅広い応用展開が求められる中, 電場印加により形成される流動 に関して幅広い研究(7)-(9)が進められている，誘電泳動が形成される電場環境において，電気分解が誘起される電 場条件と電気力線に沿って粒子が駆動される顕著な誘電泳動を示寸電場条件との中間となる電場強度・電場周波 数条件において，電極極近傍の局所的な電荷特性や溶媒へのジュール熱の効果などで電極近傍領域に積極的な交 流電場誘起流動を形成することが可能である.このような流動を積極的に用いたマイクロミキシングなどのマイ クロ流体デバイスー利用するための応用 ${ }^{(10)}$ やナノダイヤモンドなどのナノ粒子との組み合わせることによる微 細加工一の応用 ${ }^{(11)}$ など, 活発に研究が進められている.この流動は電場の不均一さが局在化する電極近傍に形 成されるものであり，電極の大きさと同程度の活発な流動が形成され，電場条件により流動形成を制御可能であ る. しかしながら, このような微小領域に形成される流動は, 先駆的な研究にはじまる平面平板電極群近傍に形

\footnotetext{
*原稿受付 2011 年 5 月 25 日

*1 正員, 首都大学東京 大学院 理工学研究科（干160-0016 東京都八王子市南大沢 1-1）

E-mail: obara@tmu.ac.jp
} 
成される流動に着目した研究 ${ }^{(12)}$ やこれらを応用した DNA やCNT，微粒子などのマニピュレーション ${ }^{(13)}$ に関 する研究はなされているものの, 応用・適用範囲の広い三次元的な棒状電極に着目した研究はなされておらず, どのような流動が形成されるのかさえ十分に明らかにされていない. 電場条件の影響や電極形状の流動形成に与 える影響などをはじめ，基本的な流動形成特性すら明らかにされていない.

以上の背景から，本報告では，三次元的な棒状電極に着目し，特に先端部が先鋭化された電極近傍に形成され る交流電場誘起流動の構造ならびに特性を明らかにするために, 流動特性を画像計測ならびにマイクロ PIV 計測 により取得し，電極極近傍に形成される流動特性ならびに流動形成にあたえる電場強度の影響を評価する.

\section{2. 実験装置および方法}

実験装置を図 1 に示寸. 実験装置は一対の電極を含む流動形成部, 電場形成用電源供給装置, 倒立顕微鏡から構成される. 流動形成部は, ガラスプレート上に配置された一対の電極間とし, 電極は先鋭な先端部を有する棒状先鋭電極と対極となる 平板電極を一組として用い, この流動形成部に供試流体を滴下し計測をおこなった. 電極先端から平板電極までの電極間距 離 $l$ として同一平面上に配置した. 棒状先鋭電極は, 先端部の形状の異なる 3 種類を用いて計測をおこなった. 直径 $d=50 \mu \mathrm{m}$ の白金細線を $\beta=30^{\circ}$ で切断した楕円断面を有する棒状先鋭電極 Type $\mathrm{A}$, 細線を垂直 $\left(\beta=90^{\circ}\right)$ に切断した円形断面を有す る鈍頭である Type B，ならびに円錐状の先鋭部を有する Type C を用いた. 本報告では, 特に，電極近傍部に安定した流動 を形成可能な Type A を中心として整理した. 電極は電場形成用電源供給装置に接続されており, 供給装置は信号発生器

(IWATSU, SG-4105) と高電圧アンプ（NF，HSA4011）ならびに印加電玻形を確認するためのオシロスコープから構成 されており, 信号発生器で生成した信号を高電圧アンプにおいて増幅し, 電極に供給することによって, 電極間の供試流体 に電場を形成した．観察・計測には，倒立方顕微鏡を用い，CCD カメラならびに高速度カメラ（IDT, MotionPro X3）によ り取得した画像情報を用い計測を行った. 光源は, ハロゲン光源を使用し, 適宜フィルタを使用した. 計測は, 顕微鏡下で 取得される画像情報から相互相関法によるマイクロ PIV 計測を用い速度場情報を取得した. なお，本報告では電極先端近 傍部に着目し, 先鋭化電極先端部中心を座標系の原点とし, 電極軸方向を $x$ 軸, 垂直方向 $y$ 軸をとし, 計測面に垂直な深さ 方向を $z$ 軸とした. 供試流体は精製水に $1 \mathrm{wt} \%$ 以下の蛍光ポリスチレン粒子（Duke, $1 \mu \mathrm{m}$ ）を分散させ作成し，必要量を滴 下し実験を行った. 印加電場条件は電極間距離ならびに供給電源条件を変化させ，電極間距離 $l=400 \mu \mathrm{m}$ とし，印加電場強 度 $E=0-200 \mathrm{~V} / \mathrm{mm}$, 印加電場周波数 $f=100-1 \mathrm{MHz}$ の範囲で評価した. 印加電場波形は矩形波形とした.

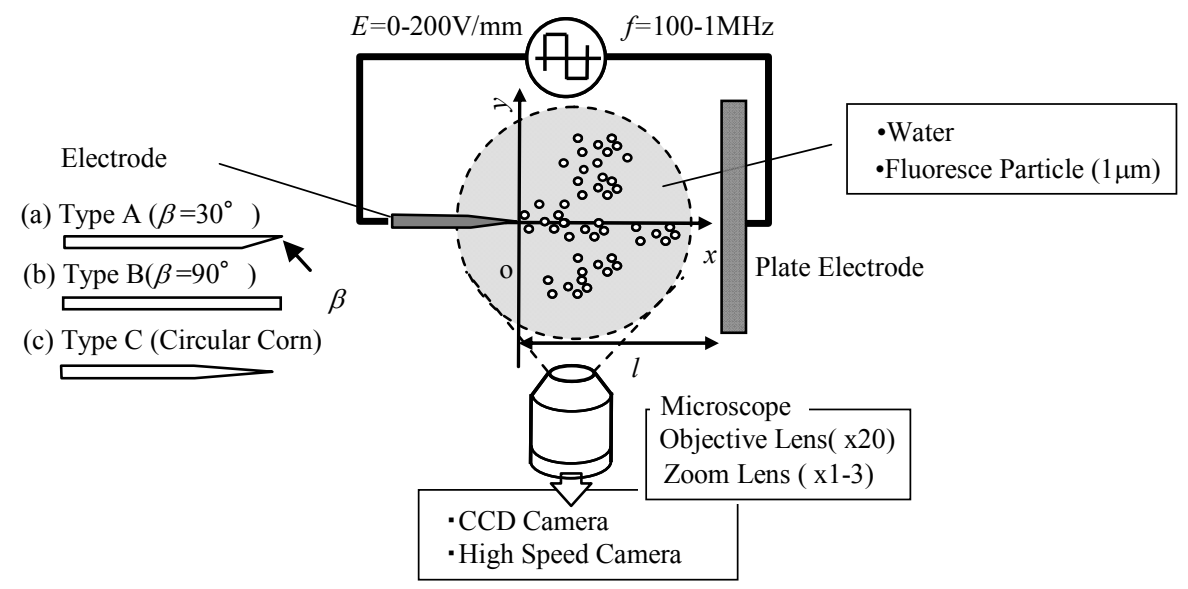

Fig. 1 Experimental apparatus and Configurations of Sharp Electrodes 


\section{3. 結果および考察}

\section{$3 \cdot 1$ 流動形成様相}

図 2 に画像観察の一例として交流電場印加により棒状先鋭電極（TypeA）近傍部に形成される交流電場誘起流 動の様相を示す．電極近傍部に気泡発生が示される電気分解が誘起される条件より低電場強度, 高周波数の条件 と, 粒子・溶媒の誘電特性に合わせて誘電泳動が支配的となる高周波数電場条件との中間領域となる電場条件下 において，棒状先鋭電極先端部近傍に電極径の数倍規模の積極的な流動が形成される.この流動は，電極形状に よりその流動構造の安定性は異なるものの，いずれの電極形状においても形成電場条件の交流電場印加により形 成される. 各電極形状における流動形成特性を表 1 に整理する. 前述の棒状先鋭電極(a)TypeA においては, 電極 先端部に 2 つ大きな循環流を有しており, 若干のゆらぎはあるものの, 安定した位置に流動が形成される.ま た後述するとおり電場条件によりその規模は変化を示寸ものの，ほぼ同位置に形成される，一方，先端部が円筒 状である(b) Type B ならびに円錐状である(c) TypeC においては, Type A と同様の電場条件下において交流電場誘 起流動は形成されるものの, 観測断面内に安定して形成されず, 摇らぎの大きい不安定な流動構造を示す.これ は, 電場強度の集中寸る角部が軸対称な円筒状（TypeB）あるいは点状(TypeC)であることにより三次元的に不安 定に形成されるためではないかと考えられる. 一方, TypeAにおいては切断した楕円断面を有しており, この断 面上において誘起される流動と先端部の局所的な電場の非対称性もあることから, 誘起される流動に偏りがあり, その効果によって安定的にほぼ同位置に流動が形成されると考えられる. 今後, 形成機構解明にあわせて切断角 度, 楕円部面積の影響など詳細な評価が必要であると考えられるが，電場印加により誘起されるこの流動を利用 するためには TypeA が有用であると考えられる.

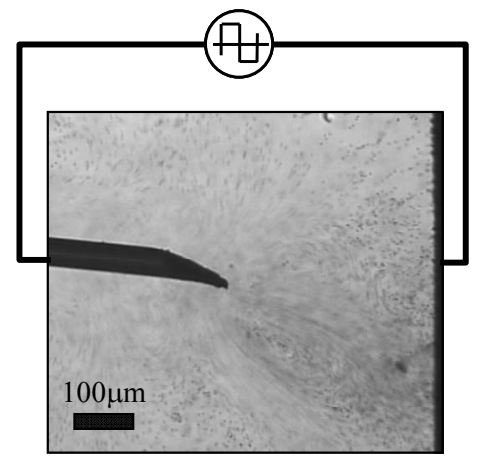

Fig. 2 Flow pattern of Electric Field Induced Jet near the Sharp Electrode (Type A)
Table 1 Configuration of Electric Field Induced Flow near Sharp Electrode

\begin{tabular}{|l|l|l|}
\hline Type & Flow Pattern & $\begin{array}{l}\text { Flow } \\
\text { Condition }\end{array}$ \\
\hline (a) Type $\mathrm{A}\left(\beta=30^{\circ}\right)$ & \\
\hline (b) Type $\mathrm{B}\left(\beta=90^{\circ}\right)$ & & Stable \\
\hline (c) TypeC (Cone ) & & Unstable \\
\hline
\end{tabular}

図 3 に棒状先鋭電極（TypeA）近傍部に形成される交流電場誘起流動様相を速度ベクトルにより示す。例とし て, 印加電場強度 $E=175 \mathrm{~V} / \mathrm{mm}$, 印加電場周波数 $f=1 \mathrm{k} \mathrm{Hz}$ における分布を示す. なお，計測条件の制約上対向す る平行平板電極に対して角度を有して先鋭電極が配置されているものの，先鋭電極近傍の局所電場の影響が支配 的であり平行平板電極との角度によらず同様の流動が形成されることを確認している．交流電場印加により電極 間に電場が形成される。この電場の中でも特に局所的に不均一かつ集中すると考えられる電極先端部近傍を起点 として流動が誘起される。あわせて，電極側面に向かう流動が形成されており，これらにより電極先端部近傍領 域に大規模な循環流をともなう流動が連続的に誘起される。この流動は他断面での計測結果などから，電極先端 近傍域に三次元的な流れ構造を有している. 他の電極形状においては三次元的な構造が顕著となり，計測断面外 に循環を有する流動を形成する場合もある。TypeA の電極形状においては，この計測断面内に安定して流動が形 成されており, 楕円状の切断面上に誘起される流動が安定した流動形成に重要な役割を果たしていると考えられ, 電場ならびに流動形成拘束条件となる電極形状をより詳細に検討することでこの流動を任意の位置に誘起し，積 極的かつ効果的に利用することが可能であると考えられる. なお，図示はしていないが，この交流電場誘起流動 が形成される印加電場周波数条件は, 電気分解の生じる周波数より高い周波数帯において形成され, 粒子が配向 
し駆動される誘電泳動が示される周波数条件までの周波数条件下において形成される. 本電極条件においては 100-1MHz において交流電場誘起流動は観察され，この周波数条件内であれば，その規模は異なるものの同様の 流動が形成される.

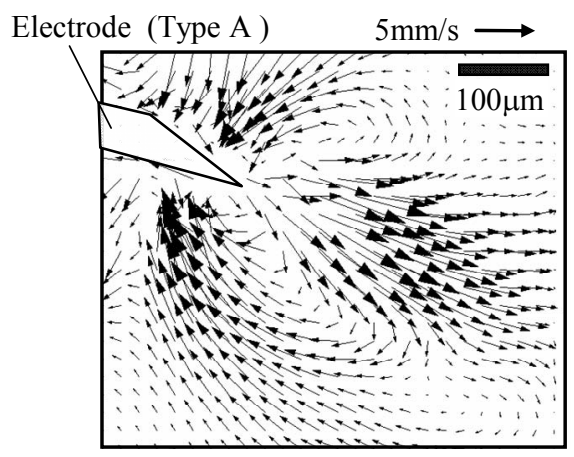

Fig. 3 Electric Field Induced Flow near the Sharp Electrode

\section{$3 \cdot 2$ 流動形成電場条件}

$(E=175 \mathrm{~V} / \mathrm{mm}, f=1 \mathrm{kHz}, l=400 \mu \mathrm{m})$

図 4 は印加電場強度・周波数変化により形成される様相特性を模式的に整理した図である. 各記号は(a)気泡発 生をともなう電気分解, (b) 交流電場誘起流動, (c)誘電泳動を示しており, 背景の色調変化は交流電場誘起流動 形成条件を模式的に示している. 印加電場周波数が $100 \mathrm{~Hz}$ 以下の小さい条件においては，点電極近傍部に気泡発 生が確認され，電気分解が誘起される，図中の条件においては，活発な反応は示されず微細な気泡が電極近傍に 停滞し，気泡の離脱に対応した不規則な流動が形成される。一方，印加電場周波数が $100 \mathrm{kHz}$ 以上の高い条件に おいては，粒子は鎖状クラスタを形成し，電場勾配に対応して移動する誘電泳動が支配的な様相を示す。誘電泳 動が支配的となる高周波数の電場条件と電気分解による気泡発生が観察される電場条件の中間となる電場条件に おいて，局所的な循環流をともなう交流電場誘起流動が形成される. 交流電場誘起流動形成条件は，色調変化で 示すように後述する詳細な条件においては印加電場強度への依存性もあるものの, 印加電場周波数が支配的であ る.

図 5 は気泡発生をともなう電気分解と交流電場誘起流動形成の境界となる詳細な電場条件を示す. 印加電場周 波数 200-800Hz 程度の条件においては，印加電場強度の変化にともない，気泡をともなう電気分解ならびに交流 電場誘起流動のいずれかの様相を示す．印加電場周波数を固定し，電場強度を増加させることにより流動が観察 されなくなり，気泡が発生し電気分解の規模が大きくなり気泡発生が支配的となる. 同様に，印加電場強度を固 定し，印加周波数を減少させることにより気泡が形成され，電気分解が示される. 図示は割愛しているが，流動 形成条件下においては印加電場強度の増加，印加周波数の減少にともないにともない交流電場誘起流動の規模は 大きくなる．また，誘電泳動が支配的となる条件に近い比較的に高い周波数条件においては，流動形成下におい ても鎖状クラスタが観察され，電気力線方向への伸張を示すなど両現象が同時に誘起されているものと考えられ る. なお，各様相のしきい值となる条件は，液性ならびに導電率，誘電率，PH 值などの物性值に依存すると考 えられ，物性值と誘起される流動の詳細な整理については今後の課題である。ただし，本現象は，ここで示した

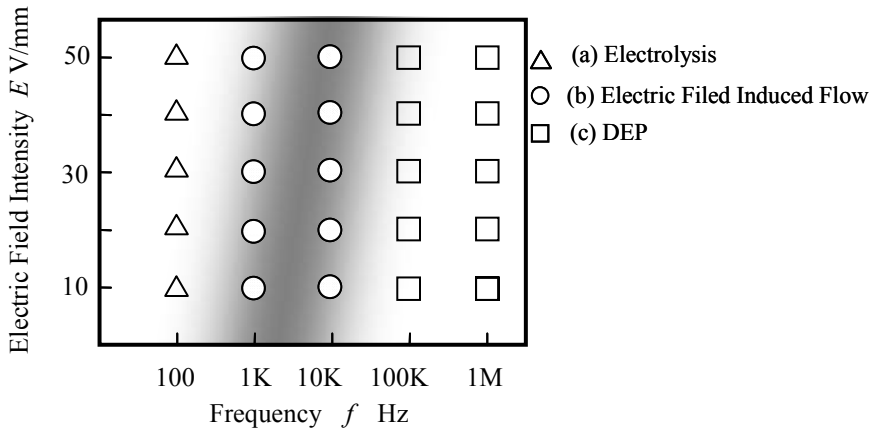

Fig. 4 Classification of Flow Configurations

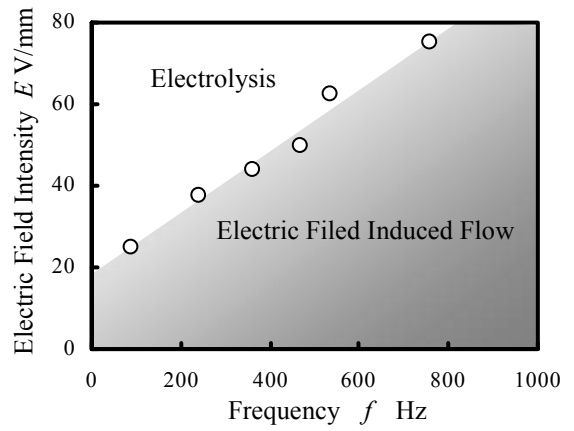

Fig. 5 Threshold Conditions of Electric Filed Induced Flow 
蛍光粒子の場合だけでなく，精製水中に分散させたダイヤモンド粒子，ナノダイヤモンドにおいても同様の傾向 を有することを確認しており, 本報告での流動形成特性を誘電率など各物性值に着目し詳細に整理することで, ナノスケールの新しい加工法への適用に向けた技術確立が可能となると考えられる.

\section{$3 \cdot 3$ 電場強度変化による流動変化}

図 6 に印加電場周波数 $f=1 \mathrm{kHz}$ における印加電場強度 $E$ の変化による速度分布を示す. 電極先端近傍, $x / d=2.8$ 断面上の $x$ 方向, $y$ 方向速度を合わせて評価した速度の大きさ $|v|$ をプロットしたものである. いずれの印加電場強 度においても, 電極先端近傍部である $y / d=0$ 近傍に極大值を有しており, 印加電場強度の増加とともにその大き さも増大している，この極大值は，速度べクトル分布において示された電極先端近傍部の交流電場誘起流動に対 応している．なお，ここでこの速度を各条件における断面上での極大速度と定義する．また， $y / d=2$ 付近にも第 2 の極大值を有しており，これは循環流として示された電極面に向から流れに対応したものである．その大きさは 先端部からの交流電場誘起流動の速度に比し小さいが, 先端部状に誘起される流動と同様に印加電場強度の増加 にともない速度増加を示す。

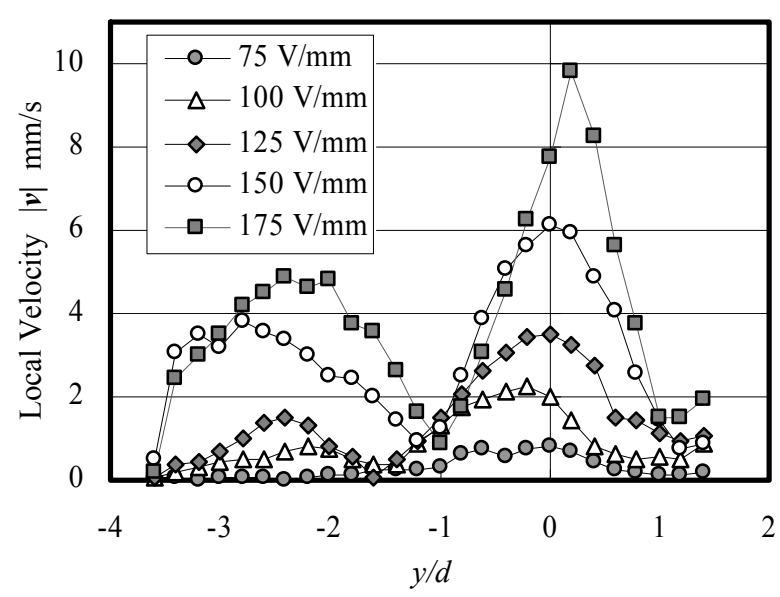

Fig. 6 Velocity Profile ( TypeA, $f=1 \mathrm{kHz}, l=400 \mu \mathrm{m}, x / d=2.8$ )

図 7 は印加電場強度変化による交流電場誘起流動の極大速度変化を示寸. 前述の, $x / d=2.8$ 断面上の速度分布に おける極大速度 $|\mathrm{v}|_{\max }$ を各電場強度に関して整理した図である.ここでは, 印加電場周波数 $f=1 \mathrm{kHz}$ における結果 を示寸. 印加電場強度の増加にともない誘起される極大速度も増加を示寸.この増加特性は, 印加電場強度と $|\mathrm{v}| \max$ $\propto 0.00002 E^{2}$ の関係を有しており, 電極表面極近傍の局所的な電荷特性が流動形成を支配していると考えられる

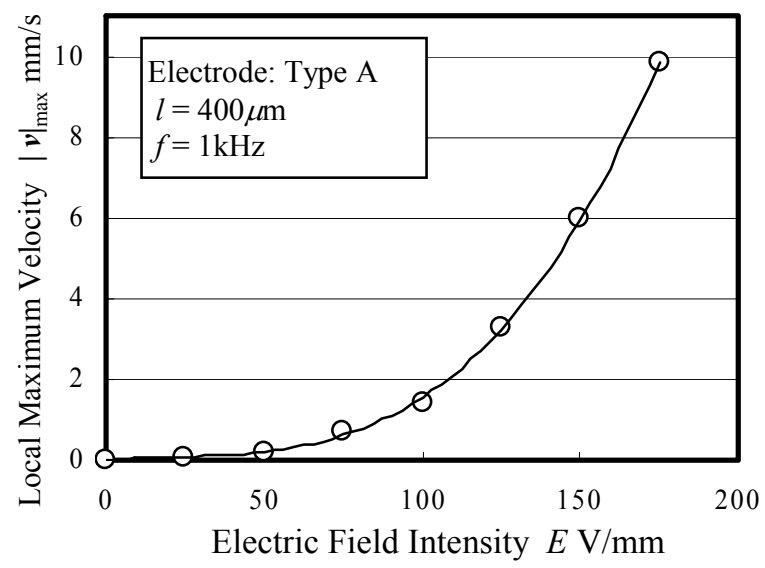

Fig. 7 Effect of Electric Field Intensity on Local Maximum induced velocity 
ものの，交流電場誘起流動形成は局所電場勾配による電場強度の 2 乗に比例し作用寸る誘電泳動力とも関連して 作用するものと考えられる.

今後, 流動形成機構解明のためには粒子・溶媒の誘電・導電特性と合わせた詳細な評価が必要と考えられるが, 本研究で整理された結果から, 印加電場強度変化による流動特性と先鋭化された電極の先端部形状最適化によっ て，微小精密加工やマイクロ流体デバイスに必要な局所流動形成が可能になると考えられる.

\section{4. 結 言}

本報告では，三次元的な棒状電極に着目し，特に先端部が先鋭化された電極近傍に形成される交流電場誘起流動の構造 ならびに特性を明らかにするために，流動特性を画像計測ならびにマイクロ PIV 計測により取得し，電極極近傍に形成さ れる流動特性ならびに流動形成にあたえる電場強度の影響を評価した. 主な結果を以下に示寸。

（1） 交流電場印加により楕円断面を有する非対称な棒状先鋭電極の先端近傍に循環流を有する安定した流動構 造を形成可能である.

（2）誘電泳動が支配的となる高周波数の電場条件と電気分解による気泡発生が観察される電場条件の中間とな る電場条件において，電極直径の数倍規模の局所的な交流電場誘起流動が形成される.

（3）印加電場強度の増加にともない交流電場誘起流動の極大速度も増加を示す. 印加電場強度の 2 乗に比例し て速度が増大する。

\section{謝 辞}

本研究の実施にあたり, 実験の立ち上げに協力をいただいた東京都立科学技術大学 機械システム工学科 肥 後本明佳氏, 池田敏行氏, 村本悠輔氏に深く感謝をいたします.また, 本研究は科学研究補助金（No.20560164） による支援によりおこなわれました。ここに感謝の意を表します。

\section{文献}

(1) Gascoyne, P.R.C., Vykoukal, J., Particle separation by dielectrophoresis, Electrophoresis, Vol.23, No.13(2002), pp. 1973-1983.

(2) Xuan, X., Zhu, J., Church, C., Particle focusing in microfluidic devices , Microfluidics and Nanofluidics , Vol.9,No.1(2010), pp. 1-16

(3) Ronald Pethig ,Review Article-Dielectrophoresis: Status of the theory, technology, and applications, BIOMICROFLUIDICS , Vol.4 (2010),022811.

(4) Ramos, A., Morgan, H., Green, N.G., Castellanos, A., AC Electric-Field-Induced Fluid Flow in Microelectrodes, Journal of Colloid and Interface Science, Vol. 217,No.2(1999), pp. 420-422.

(5) Green, N.G., Ramos, A., González, A., Morgan, H., Castellanos, A., Fluid flow induced by non-uniform AC electric fields in electrolytes on microelectrodes. I. Experimental measurements, Physical Review E, Vol.61, No. 4B (2000), pp. 4011-4018.

(6) Green, N.G., Ramos, A., Gonzalez, A., Morgan, H., Castellanos, A., Fluid flow induced by non-uniform AC electric fields in electrolytes on microelectrodes. III. Observation of streamlines and numerical simulation, Physical Review E, Vol.66, No.2(2002) , art. no. 026305, pp. 026305/1-026305/11. 
(7) Bazant, M.Z., Kilic, M.S., Storey, B.D., Ajdari, A. , Towards an understanding of induced-charge electrokinetics at large applied, Advances in Colloid and Interface Science, Vol. 152, No.1-2(2009), pp. 48-88.

(8) Squires, T.M., Induced-charge electrokinetics: Fundamental challenges and opportunities, Lab on a Chip, Vol.9,No.17 (2009) , pp. 2477-2483.

(9) Bazant, M.Z., Squires, T.M. ,Induced-charge electrokinetic phenomena, Current Opinion in Colloid and Interface Science, Vol. 15,No.3(2010), pp. 203-213.

(10) Chang, C.-C., Yang, R.-J., Electrokinetic mixing in microfluidic systems, Microfluidics and Nanofluidics, Vol.3,No.5 (2007) ,pp. 501-525.

(11) 小原弘道, 村本悠輔, 田代伸一, 微細加工のための電場誘起されるナノダイヤモンド分散流体の流動特性, 機構論, No.090-1 (2009) ,pp.455-456.

(12) Castellanos, A., Ramos, A., González, A., Green, N.G., Morgan, H., Electrohydrodynamics and dielectrophoresis in microsystems: Scaling laws, Journal of Physics D: Applied Physics, Vol.36, No.20(2003), pp. 2584-2597.

(13) Velev, O.D., Gangwal, S., Petsev, D.N., Particle-localized AC and DC manipulation and electrokinetics , Annual Reports on the Progress of Chemistry - Section C, Vol.105(2009), pp. 213-246. 